\title{
Gold Dreams, Gold Nightmares: The Social Construction of Inflation as Delegitimation Discourse
}

\author{
by Adam Rafalovich \\ Pacific University
}

Sociological Research Online, 16 (1) 12

$<$ http://www. socresonline.org.uk/16/1/12. html>

$10.5153 /$ sro.2228

Received:2 Mar 2010 Accepted: 11 Feb 2011 Published: 28 Feb 2011

\begin{abstract}
Using archival data from the four most popular gold investment websites, this study is a content analysis of gold investment enthusiast ('gold bug') commentaries over a six-month time period, from November 2007 to April 2008. We examine gold bug discourse as a conspiracy narrative whose central tenet is the criticism of inflationary monetary policy. Gold bugs argue that the continual presence of inflation demonstrates the fundamental flaws of global capitalism and the illegitimacy of the administrative system that operates it. The invocation of inflation is the primary way in which gold bugs forecast economic conditions and the inevitable failure of those who control global monetary policy. Based upon the ontological claim that gold is the only 'true' store of value, gold bugs posit a sharp rebuke of monetary policy, predicting a drastic increase in the price of gold and a consequent collapse of the world's fiat currencies.
\end{abstract}

\section{Keywords: Content Analysis, Gold, Conspiracy, Inflation, Monetary Policy}

\section{Introduction}

1.1 The price of gold has increased more than $300 \%$ since 2001. While there are many explanations for gold's increase in value, certain enclaves within the investing community see the increase in the price of gold as evidence for inevitable global economic collapse. Such enclaves, better known as 'gold bugs,' also see the rise in the price of gold as vindication for their opposition to the paper currencies that support the global financial system. In short, gold bugs are gold investment writers and/or investors whose viewpoints may be summarized by the following: 1) gold is the world's oldest currency because of its intrinsic value; 2) the global economy is manipulated by specific agents who prop up world currencies and demean the value of gold; 3) the global economy is nothing more than a shell game in which the purchasing power of the world's currencies will collapse; and 4) gold's value will skyrocket as a result of this collapse.

1.2 Supporting each of these views is a basic disdain for the economic concept of inflation (see Ball 2007; Constantino and Robbins 2007; Bentley and Nelson 2008, among many others), which is a common part of gold investor parlance. For example, the National Inflation Association's website (http://www.inflation.us/) is inundated with links to articles that implore aggressive investment in gold, silver, and other precious metals. As gold bugs repeatedly state, owning gold is the only protection from this pernicious economic force. Although no modern economy uses gold as a currency, gold bugs argue that gold is the only true currency of the world-one whose value will remain regardless of economic circumstance.

1.3 Inflation has also been widely discussed in economic sociology (Hirsch and Goldhthorpe 1978; Smith 1982; Goldthorpe 1983; Smith 1985, 1992 ; Peters 1997; Trigilia and Owtram 2002; Babb 2007). With regard to the economic impact of inflation there remains considerable debate about whether inflation is a growing threat to social stability (Smith 1982, 1985, 1992) or is an indicator of the power of the working class (Hirsch and Goldhthorpe 1978; Goldthorpe 1983). Hirsch and Goldthorpe (1978) generally claim that the United Kingdom's policies toward full employment demonstrate a mature and powerful working class and that inflation was positive for wages. From this viewpoint, inflation signifies a working class that has garnered bargaining power in the postwar period, preserving wages and other benefits. On the other hand, Smith (1982) argues that such policies were partially a result of the fragility of the UK economy. In addition to his assertion that it pleased the electorate, Smith (1982) argues that postwar UK economic policy which emphasized lower interest rates and the availability of credit mirrored that of economic bellwether the 
Unites States. Smith (1982) further contends that this policy served to insulate the UK from downturns in the US economy, especially periodic recessions, which inevitably proved to be more severe for the UK than the US. Hence, the policy toward full employment actually masked inflationary monetary policy; employment was continuously buoyed by lower interest rates, but that did not necessarily indicate an improving quality of life.

1.4 Similar to Smith's (1982) assertion that inflation is more a political tool than an illustration of increasing purchasing power, gold bugs contend that those who cause and manipulate inflation are powerful foes who seek the destruction of wealth for their own enrichment. In the Discussion section we argue that this critique of inflation places gold bug discourse within a 'conspiracy narrative' (Locke 2009), providing this enclave of gold enthusiasts with 'interpretive agency and social identity' (Oushakin 2009: 75). We ground our analysis within the sociology of conspiracy literature (Husting and Orr 2007; Locke 2009; Oushakin 2009; Kihn 2010, among others), discussing how gold bugs use inflation to explain the collusion between powerful agents within the global economy. Inflation, in this sense, is the major indicator of the presence of conspiring agents that serve the interests of bankers and financiers, rather than the common person. From this populist stance, gold bugs claim that monetary devaluation, the destruction of individual wealth, and economic recessions come from the concerted efforts of central bankers, politicians, and other policy makers.

1.5 This conspiracy narrative is separated into four sub-themes. First, there is the narrative of 'intrinsic value' in which gold bugs explain how gold, because of its beauty and rarity, is the oldest and most legitimate currency in the world. Second, we discuss the theme of 'policy blunders,' in which gold bugs discuss monetary policy decisions, especially the abolishment of the 1971 Bretton-Woods agreement that moved the United States and, consequently, all of the world's currencies off the gold standard. Third, the theme of 'demonic central banks' addresses how the US Federal Reserve artificially inflates markets, kowtows to special interests, and destroys individual wealth. Fourth, the theme of 'the inevitable rise of gold' rationalizes how the inflationary practices of the last forty years will mean significant financial reward for those who invest in gold.

\section{Methods and data}

2.1 Previous research has asserted that Internet forums provide a fertile environment for social organization (Klein 1999; Tambini 1999; Ho et al. 2002). Adopting an interpretive approach (Lincoln and Guba 1985; Denzin 1989; King, Keohane and Verba 1994), we set out to explore gold bug discourse through what are arguably the four most visited gold investment websites on the Internet:

www.321gold.com, www.kitco.com, www.goldseek.com and www.JSmineset.com. Each of these websites offers services for the purchase of gold, a 24-hour chart of the current spot gold price, and several advertisements for gold mining companies. Most importantly, each of these sites maintains an archive (most going back several years) of gold investment commentaries. These documents tend to offer a 'bullish' (seeing a higher price in the future) picture of gold through technical analyses, remarks about geopolitical events and, most importantly, discussions of monetary policy. Exemplifying 'archive' data described by Webb et al. (2000), such commentaries became the primary sampling units (Chamblisss and Schutt 2006) for a content analysis (Greenberg 1980; Krippendorff 1980; Weber 1985; Altheide 1987; Fields 1988; Fox and Roberts 1999; Covert 2003; Reason and Garcia 2007) of gold bug culture.

2.2 Data collection used 'theoretical sampling' (Jankowski 1991; Ragin 1994) in which the predominant themes seen in the data charted the direction for subsequent sampling. The first sample of content from these four websites comprised 40 randomly downloaded commentaries, approximating 180 pages of content dated from November 2007 to April 2008. Adopting an 'open coding' (Glaser 1978) approach in which all major themes in the data were categorized indiscriminately, we began to search for narratives illustrating gold bugs' preference for gold above other investment strategies. Throughout this open coding process we repeatedly encountered discussions of inflation, which were invariably linked to bullish views on gold. Within this initial content sample, gold bugs discussed inflation more than any other economic concept. We then expanded our sample to 220 commentaries (approximately 600 pages of content) within the above five-month timeframe and again open coded. The concept of inflation again proved to be the most salient. Once it became clear that we had reached a 'saturation point' (Glaser and Strauss 1967; Glaser 1978; Strauss and Corbin 1990) with inflation as the central and galvanizing idea of gold bug discourse during this timeframe, we returned to this content sample specifically seeking commentary that addressed inflation. We then 'selectively coded' (Glaser 1978) the data set, focusing upon various discussions of inflation. Addressing inflation narratives as the principle theme, we divided these into specific substantive areas discussed in the findings section.

\section{Findings}

3.1 Gold bugs believe that gold's value is timeless and that severe inflation is unavoidable given the decoupling of a paper currency such as the US dollar from gold. In short, paper currencies are doomed without the backing of gold. Such fatalism within gold bug discourse is based upon two ontological assumptions. The first concerns what gold 'is,' while the second addresses what gold 'will do.' The former establishes gold as the only time-tested currency vis-à-vis the litany of paper currencies that form the financial backbone of the global economy. The latter predicts the rise of the value of gold in direct relation to the inflationary demise of the current currency system. This twofold ontology argues that gold is the world's only legitimate currency, and that gold will inevitably increase in value as inflation decimates paper currencies.

\section{The intrinsic value of gold}

3.2 A principal narrative in the data addresses why gold has endured as a medium of exchange. The below excerpt links the historical value of gold to its aesthetic appeal: 
Gold has functioned as an adornment and store of value for more than 6,000 years. The earliest gold jewelry dates from the Sumerian civilization that flourished around 4,000 BC. Gold's intrinsic beauty, warmth, glitter, sensuality and spiritual richness have evoked powerful human emotions throughout history (Dienhart 2007).

3.3 Portraying gold as something intrinsically evocative even 'spiritual' attempts to elevate gold above other standards of value. As gold bugs repeatedly claim, the relationship between civilization and gold involves a connection between the yellow metal and the deepest parts of humanity.

3.4 These historical accounts of gold depict a more 'honest' time in which value was standardized by gold. This gold-based standard of value eventually gave way to the interests of government authority and the advent of paper currency:

History tells us that for centuries gold and silver coins were universal currencies. But when the printing press was invented, so was paper currency. The first paper currencies were mere warehouse receipts for gold or silver in a storage facility (think bank). ... In effect, we were on 'a gold standard,' with 'gold-backed paper.' Paper has become currency in common usage, and eventually the people now think of the receipts (currency) as money all by itself (Ruff 2007).

3.5 Initial forms of paper currency served as receipts for precious metals that were stored in what we today call a bank. These 'receipts' represented a commitment on behalf of a monarchy or nation-state to supply the receipt owner with gold upon request. The conversion of a denomination of paper currency into a specific gold weight was corrupted, gold bugs argue, by authoritarian interests and their use of the printing press. Ruff (2007) continues: '... as governments began to buy votes or finance wars, they yielded to the temptation to simply print more 'receipts."

3.6 From this viewpoint the printing press debases the natural value of any 'hard' (in limited supply) commodity (Pomeranz and Topik 2006). In addition to its aesthetic appeal, gold can only be discovered and acquired through various degrees of industrious activity. As gold cannot be 'created,' its value is a product of rarity and the considerable effort that must be expended in order to acquire it. This natural value has been upset, according to gold bugs, as the new order of monetary value is kept intact only by the legitimacy of those who print money.

\section{Policy blunders: Abolishing Bretton-Woods and the gold standard}

3.7 The narrative of the impact of decoupling gold from paper currency continues with accounts of the 1944 Bretton-Woods agreement. As gold bugs argue, the Nixon Administration's decision to back out of BrettonWoods in 1971 was an unfortunate result of the United States' military and economic entanglements and a fatal blow to the integrity of the US dollar:

Under the Bretton Woods monetary system, which lasted from 1944 to 1971, currencies were exchangeable into dollars at fixed rates and the dollar was exchangeable into gold. Central banks could not simply print money without an eye on their reserves of gold. But following two oil shocks and bloated spending to finance the Vietnam War, President Nixon closed the gold window when foreigners demanded gold in lieu of dollars. Then, as now, a savingschallenged America printed dollars via its banking system, pumping out trillions of fiat obligations (Ing 2008).

3.8 Similar to Ruff's (2007) comments about the 'temptation' of the printing press, the above discusses the policy decisions (the war in Vietnam) and market conditions (oil shocks) that led to 'fiat obligations' far beyond the value of American gold reserves. Prior to the abolishment of Bretton-Woods, central bankers were constrained, according to gold bugs. After 1971, when countries began demanding gold in exchange for the increasing amount of dollars they owned, the fiat (read: Nixon) was left with little choice other than to abandon the gold standard. The US dollar would be exchanged only in relation to other fiat currencies.

3.9 The integrity of the US dollar, according to this excerpt and many others within the data set, was preserved through two key provisions of Bretton-Woods. First, Bretton-Woods established the US dollar as the primary reserve currency of the world. Second, in order to maintain the integrity of this now international reserve currency, the United States committed to not printing more dollars than were in its gold reserves, and agreed to fix the gold price at \$35 per ounce. The abandonment of Bretton-Woods moved the entire world economy off of the gold standard. But, because it was used for decades as a ubiquitous store of value, the US dollar remained the de facto world reserve currency. As many gold bugs argue, this began the United States' dependency upon other nations who must continuously buy US treasury notes in order to keep the American economy afloat. Without the gold standard, gold bugs contend, Americans are wholly reliant upon the nations who have a vested interest in holding the US dollar as a reserve currency, and who trust that the United States will not default on its debt obligations. One account summarizes this dependency as a 'disease' of the entire global economy:

The disease stems from a malfunctioning and dysfunctional international monetary system in which governments can create new local money at will without restriction. This has been the case since 1971 when the Bretton Woods system collapsed and all currencies floated against one another.

Since 1971 the world has embarked upon a binge of undisciplined credit and debt creation. It is the first time that this has happened on a world-wide scale and the unpalatable consequences of this orgy are revealed in the symptoms section above (Field 2008). 
3.10 Gold bugs repeatedly argue that the abandonment of the gold standard begins the inflation game in earnest. The 'orgy' of economic growth continues through the expansion of credit and debt markets. As the United States was compelled to inflate the money supply in order to finance debt on federal, municipal, and consumer levels, gold bugs argue that it is only a matter of time before the nations who purchase American debt will realize that 'the emperor has no clothes.'

\title{
Demonic central banks: The Federal Reserve, 'Helicopter Ben' and the 'dilution of wealth'
}

3.11 According to gold bugs, this emperor is the Federal Reserve System ('the Fed') in the United States. Argued by proponents to be a necessary response to the Financial Panic of 1907 in which the stock market fell $50 \%$ and people flocked to numerous banks and trusts to withdraw money, the 1913 establishment of the Fed stemmed from the belief that this central banking system was crucial to providing financial stability to the United States and to its trading partners. As the third attempt to establish a central bank for the United States, the Fed was designed to prevent runs on banks by being able to quickly respond to the money supply contractions and expansions that are indicative of an 'elastic' currency (Bryant 1997). The many aspects of the Fed include a presidentially-appointed Board of Governors that is overseen by a 'Fed Chairman.' Amongst its many functions, the Fed controls two key interest rates: the 'federal funds rate,' which is the interest rate banks charge each other for the overnight loan of federal funds, and the 'discount rate,' which is charged to individual banks who borrow directly from the Fed. Gold bugs personify the Fed through its past and present chairmen, including Paul Volcker (Chair from 19791987), Alan Greenspan (Chair from 1987-2006), and current Fed Chairman, Ben Bernanke.

3.12 Throughout the data Ben Bernanke is the target of relentless ad hominum remarks. As Fed Chairman, Bernanke personifies the usurpation of individual wealth and a fiscal policy that relies upon inflation, according to gold bugs. This opinion of the Fed is especially salient in gold bug commentaries about the global credit crisis that erupted in August of 2007. Themes in the data repeatedly illustrate that the Fed's response to this crisis betrays its raison d'être of monetary inflation: '... the Fed will likely print as much money as necessary to prevent nominal prices from collapsing. In fact, in the infamous speech that spawned his 'helicopter' sobriquet, Ben Bernanke explained how the printing press can be used to stop deflation dead in its tracks' (Schiff 2007). Another account describes Bernanke's role this way:

He thought he could just get into his proverbial chopper and throw confetti-money out the Fed's discount window with both hands, all to the roaring joyous cheers of the markets below.

But it isn't working as planned. He's stuck. He can't even get his helicopter off the ground.

\begin{abstract}
...Although the Fed's actual function is to trap the world in never-ending debt-inflation, it can carry its mission out for only so long as the world doesn't smell the rats that are running the institution. The world must believe that the Fed's job is to control price-inflation - or else the jig is up.
\end{abstract}

\begin{abstract}
If Bernie throws his load of confetti by buying even more long term treasuries to depress interest rates... Ben will lose all of the 'credibility' his predecessors have so carefully built up. If he doesn't, however, the credit crunch will grab him by the neck and squeeze until he passes out - and the Fed's credibility will still be gone (Willie 2007).
\end{abstract}

3.13 According to Willie (2007) 'Ben' is ineffective in a credit-constrained environment, but will still adopt his trademark inflationary stance toward price stabilization. As numerous accounts from the data set assert, the Fed must present itself as a strong dollar advocate, and opponent of inflation, but economic realities - those that necessitated the existence of the Fed in the first place-mandate that the Fed support a never ending cycle of debt creation, and consequent inflation. Hence, the value of the US dollar is reduced to 'confetti.'

3.14 The above accounts and dozens of others within the data set invoke Bernanke's dubious nickname 'Helicopter Ben,' referring to a speech given before the National Economists Club, in Washington, D.C. on November 21, 2002. Bernanke's address, 'Deflation: Making Sure 'It' Doesn't Happen Here,' explains his belief in the power of the printing press:

Like gold, U.S. dollars have value only to the extent that they are strictly limited in supply. But the U.S. government has a technology, called a printing press (or, today, its electronic equivalent), that allows it to produce as many U.S. dollars as it wishes at essentially no cost. ...We conclude that, under a paper-money system, a determined government can always generate higher spending and hence positive inflation (Bernanke 2002).

3.15 Next, Bernanke invokes Milton Friedman's helicopter analogy:

Even if households decided not to increase consumption but instead re-balanced their portfolios by using their extra cash to acquire real and financial assets, the resulting increase in asset values would lower the cost of capital and improve the balance sheet positions of potential borrowers. A money-financed tax cut is essentially equivalent to Milton Friedman's famous 'helicopter drop' of money (Bernanke 2002).

3.16 These statements by the current Fed Chairman bolster gold bugs' belief that the financial system has, at best, a limited amount of tools in dealing with financial crises and, at worst, is the actual reason behind such crises. This is particularly the case when it comes to commentary about the Fed's setting of interest rates and its impact upon the gold price. For example, in early November 2007, when the spot price for one 
ounce of gold reached $\$ 800-$ a price not seen in twenty-seven years - one gold bug states:

... where is the excitement? We have seen gold breach 800 now. Does anyone really care or is everyone asleep?

Well...the Fed lowered the rate on Wednesday. Anybody surprised? Unfortunately, the 'magic bullets' will not work this time. Their major contribution will be to speed the dollars (sic) decent. Will the rate cut truly do any good? What is just down the road?

Gold naturally went lower the day after the rate cut. Had to distract attention from the public. But it will continue to rise when no one is looking. Does it bother you to know markets are manipulated? The Dow Jones is manipulated and the general public loses no sleep because of this fact. Everything is manipulated to one degree or another. And if its not you better believe there are forces in the background attempting manipulation (Vaughn 2007).

3.17 The above exemplifies a key narrative in the data concerning how the price of gold is linked to interest rates and how lowering the federal funds rate favors the financial sectors of the economy. Indeed, gold bugs consistently accuse the Fed of market manipulation. Lowering interest rates directly attacks the price of gold and distracts people from the diminishing credibility of the Fed. As Vaughn (2007) mentions: '(the Fed) Had to distract attention from the public.' Schoon (2008) argues that this distraction is necessary because 'the custodians of credit are so intent on keeping the price of gold low. A low price of gold implies investing in paper IOUs, government and corporate debt and other credit based instruments is safe and profitable.' As these accounts illustrate, the Fed propagandizes debt-based buying power.

3.18 Gold bugs claim that the Fed, acting as a proxy for those who profit from the fiat currency system, unnaturally inflates stock prices and distorts the truth about the decreasing legitimacy of such currencies. Katz (2008), writing for the The Gold Bug newsletter claims that the mass media are a pawn of the Fed and manipulate public opinion about the necessity of lower interest rates: 'The stock bear move of October to January was not a real bear market. It was mostly a lot of hype in the media designed to cover Bernanke's tracks and justify his easing.' Similar to Vaughn (2007), Katz (2008) claims that the reduction of interest rates is a way of manipulating people to invest money in the stock market. Katz (2008) ends his commentary with two questions about the Fed's manipulation: 'How long can the Fed successfully bull the stock market?' and, in an indirect reference to inflation, 'Will Ben Bernanke completely destroy the United States of America?

3.19 Gold bugs clearly believe that cutting interest rate shows the fundamental preference that the Fed has for Wall Street and its stockholders who invest in an inflation-based economy. What is startling about gold bugs' discussion of the relationship between the gold price and interest rates is the paradoxical role that the Fed appears to play in manipulating markets. On one hand, gold bugs claim that the Fed manipulates gold prices through interest rates, but on the other, they frame the Fed as completely helpless. As Willie (2008) states: 'Gold will rise as the globe finally reckons that the US Fed, traditionally the most powerful among the central bankers, is IMPOTENT, TOOTHLESS, AND IRRELEVANT (Caps in original). Further, in a detailed discussion of the Fed's preference for Wall Street, Ash (2008) states:

This week marked the six-month anniversary of the Fed's first cut to US interest rates during the current world banking crisis.

The price of gold meantime - whose only real utility, unlike all other natural resources, is as a store of value - has now risen in twenty of the last 27 weeks. Spot gold prices have gained $44.7 \%$ since the morning of August 17th, just before the Fed announced its 'extra-ordinary' rate change.

...Oh sure, Bernanke was talking about the kind of gains he'd expect to see inside one day! But slashing the Fed funds target by 225 basis points since the global banking crisis provoked him to act back in August, Bernanke hasn't even got $6.75 \%$ across six months...let alone a 13.5\% rise on Wall Street (Ash 2008).

3.20 This is a telling example of gold bugs' fatalism. The primary economic tool that. The Fed has used since the abolishment of the gold standard -the setting of interest rates -is no longer effective in a world where fiat currencies have no objective standard of value. Evidence of the Fed's ineffectiveness is the gold price which, according to gold bugs, will 'see through' any fiat currency.

3.21 Gold bugs also question the effectiveness of the current financial system through the invocation of previous policy makers. Although gold bugs generally revile the Fed, they are particularly critical of the most recent policies of Allan Greenspan and current chair Ben Bernanke, both of whom have lowered interest rates to unseen levels in the post-war era. Gold bugs argue that the Fed attempts to maintain a reputation as a fighter of inflation and, consequently, a champion for the value of the US dollar, but this reputation flies in the face of interest rate cuts. In other words, the US dollar cannot gain value if the central banks make the price of dollars cheaper. This argument is thrown into sharp relief through several gold bug commentaries about the legacy of Paul Volcker, Fed Chairman from 1979 through 1987, who raised the federal funds rate above twenty-percent in 1981. Seen by gold bugs as the only solution for 'stagflation' (inflation combined with economic stagnation; see Bruno and Sachs 1985), Volcker's money supply reduction measures are touted as the last sincere attempt at maintaining the value of the US dollar. One commentary entitled 'Volcker's Legacy - Squandered' states:

Fed chief Paul Volcker was able to lift the US out of its '70s stagflation funk by ratcheting up the federal funds rate to the point where investors could no longer resist the huge interest gains luring international assets back out of gold and into dollars. 
... When interest rates are high and stocks are floundering, saving money makes sense, of course, but as this situation was soon reversed by consistently dropping rates as the '90s arrived, saving was 'out,' stock buying was 'in,' and the construction of a 100 percent delusionary (sic) wealth-edifice was in full swing (Wallenwein 2008).

Indeed, several accounts within the data contend that keeping interest rates moderately high is the next best way to minimize inflation and preserve the integrity of the US dollar.

3.22 This commentary continues with the discussion of 'asset bubbles,' in which easy credit made possible the American dot-com bubble of the 1990s and housing bubble from 2001 through 2006. As Saxena (2007) states: 'It (the Fed) is more interested in creating more inflation and giving the illusion of prosperity through even higher asset-prices.' In addition, the below commentary argues that the antiinflation stance championed by Volcker has given way to stock buying greed and, again, the interests of the banking system:

In August 1979, Paul Volcker became the chair of the Federal Reserve and start (sic) to fight inflation by radically raising interest rates. Today, Chairman B. Bernanke, in an effort (to) alleviate the pain in the ailing banking system, is aggressively lowering interest rates.

28 years ago, the United States was the biggest creditor nation in the world. Now, the opposite is the case - US is the largest debtor. This, along with the Fed policy is causing the dollar to fall to historic lows (Sobolev 2007).

3.23 Contrasted with Volcker, Benanke is framed as an agent of Wall Street, someone more interested in the banking system than the impact of inflation. Suggesting that the Fed can do little to promote sustainable economic growth, the above excerpt outlines how the level of debt carried by the United States precludes the raising of interest rates. Sobolev (2007) adds that this dollar-weakening policy will benefit gold: 'We reiterate that the gold bull market has a long way to go. Don't be afraid to miss the boat - there are many opportunities ahead. Hold your positions and buy the dips.' According to gold bugs, our economy is much more fragile than it was during the Volcker years as consumer debt-something Volcker was not particularly concerned about - has made any monetary policy other than inflation implausible.

\section{The inevitable rise of gold}

3.24 Consumer debt, according to gold bugs, is the shaky foundation upon which the ethos of capitalism rests. Simply put, the post-Volcker era mistakes growing credit with a growing economy. And, as several previous excerpts illustrate, this is perpetuated by manipulating consumers into thinking that credit equals wealth. As gold bugs repeatedly argue, the continuous need for more and more cash outstrips the valuation of any fiat currency. This flaw in the global financial system is perhaps most evident in the Fed's unprecedented involvement in the investment banking sector. In response to the Fed's discussion of purchasing mortgage-backed securities and effectively 'bailing out' entities who invested in them, Wiegand (2007) states that 'Greenspan started it by giving bankers, mortgage companies and consumers a free lunch. Now Congress plans to give another free lunch to derivative issuers 'for the greater good of our economy.' As Wiegand (2007) and many others argue, the low mortgage rates facilitated by Allan Greenspan's lowering of the federal funds rate to $1 \%$ in June 2003 artificially inflated home prices and now necessitates that the federal government purchase the debts consumers were unable to afford. As many gold bugs discuss, this type of government intervention is not a solution to the problem of collapsing asset prices, but rather, exacerbates it.

3.25 Another commentary claims that central banks, as entities designed to increase inflation, are blind to fundamental economic problems: 'Central bankers are intellectually dishonest about food and energy prices, routinely subtracting the 'essentials of life' from their inflation equations, and reckon that commodity price spikes are self-correcting, due to the laws of gravity' (Dorsch 2007). Gold bugs argue that such 'intellectual dishonesty' stems from the Fed's use of 'core' (excluding food and energy prices; see Peters 1997) inflation statistics as a guide for monetary policy. The core reading of inflation, as it distorts the lived reality of increasing prices, is believed to be another way of manipulating the public:
At present 'core inflation' excludes food and energy. Other components such as housing have been extensively manipulated, changed in order to try and show the absence of inflation. Psychology of government officials is reflected in the moral accountability of the public and since people are far more concerned with Bread and Circuses news (what Gary Coleman is doing or what Britney keeps in her 'special room') it is no wonder why things can be manipulated (Petch 2008).

3.26 Following the discussion of the fundamental 'blindness' of the Fed to inflation, gold bugs repeatedly claim that the Fed's policy of electronically creating money is done in the interests of fellow bankers, not the general public. Reminiscent of Ben Bernanke's 2002 speech about the 'electronic equivalent' of the printing press, the below excerpt argues that increasing the money supply, or 'injecting liquidity'

....is a euphemistic way of saying 'creating money out of thin air.' The Federal Reserve doesn't need a printing press to do this. They simply create a book entry on its balance sheet, and presto, $\$ 40$ billion (or whatever amount they deem appropriate) of new 'money' is created, which the Fed then lends to those bankers coming to it hat in hand.

Creating money this way is a barbaric process because it further debases the dollar, but is hailed by the banking insiders and their apologists as a brilliant maneuver to fight the worsening liquidity crunch. Of course it is a view of those with vested interests, and bluntly, 
3.27 The 'barbaric process' of creating dollars reduces individual buying power, and only benefits bankers and their friends in the central banking system. Discussions within the data about the disclosure of the money supply in the financial system exemplify the belief that central bankers prefer 'Wall Street' over 'Main Street.' As the following excerpt explains:

Typically absent from Fed rhetoric, however, is any mention of growth in the US money supply (up over $\$ 1$ trillion last year). In 2006, the Fed decided to stop publishing the broadest measure of the US money supply, M3. In its news release, it said that 'the Board judged that the costs of collecting the underlying data and publishing M3 outweigh(ed) the benefits.' ....It is unclear what costs were associated with the data collection as most of the individual components of M3 are still published. What is clear however is that M3, a good indicator of monetary inflation, is no longer in the public eye (Potter 2007).

Gold bugs argue that injecting liquidity may help Wall Street bankers fix their balance sheets, but at the expense of reducing the value of the money in the pockets of families on Main Street.

3.28 Gold bugs pit themselves against those who are 'blind' to the coming collapse of the fiat currency system. For example, one website from which we sampled (www.JSmineset.com) refers to fellow gold bugs as CIGAs, or 'Comrades In Golden Arms.' Contributors to the site refer to themselves as 'CIGA Mark,' 'CIGA Jane,' and so on. Whether adopting a valorizing acronym or not, gold bugs universally believe that they will benefit hugely from their investments in gold, but at the expense of seeing the world economy crumble. Hence, many gold bug accounts of the rising price of gold are imbued with despair. As one commentary states after the gold price breached $\$ 1000$ per ounce: ' $\$ 1000$ gold is a milestone - on the road to hell' (Fekete 2008).

3.29 For gold bugs, the Fed's intellectual dishonesty about the amount of inflation in the system distorts the extent to which inflation has metastasized in the financial system. In this sense the Fed continues to take deliberate steps to obfuscate its primary aims: the propping up of fiat currencies at the expense of 'real' wealth. The depiction of these continual efforts from the Fed again underscores the fatalistic march to the 'hell' of astronomical gold prices. For example, the $\$ 1000 /$ ounce price barrier for gold might only be the beginning: 'However, we can just as easily, after some backing and filling, rocket straight through the $\$ 1000$ natural resistance point and be well on the way to my $\$ 1225-\$ 1425$ Wave I target. Then, after some more consolidation, it's up, up and away to Gold's eventual $\$ 2,500$ to $\$ 5,000+$ target' (Baltin 2008). Another excerpt, arguing that protracted stagflation of the global financial system 'is most likely,' states that 'a gold forecast of 10,000 (US dollars per ounce) is perfectly realistic' (Petrov 2008). Finally, invoking the unconquerable value of gold, Schoon (2008) states: 'When paper money begins to quickly lose value, the collapse of debt-based assets will gather speed... On that day...gold will be literally priceless' (Schoon 2008).

\section{Discussion}

4.1 As Stewart (1999) points out, conspiracy theories are enticing in that they reenact trauma, moving their interlocutors through a cycle of fascination and horror. As a conspiracy narrative gold bug discourse elucidates and reviles monetary policy and policy makers, and substantiates how conspiracy theory provides an experience of victimization and vindication (Oushakin 2009; Stewart 1999). As described below, gold bug narratives that express victimization and vindication are inextricably linked to the concept of inflation.

\section{Victimization: Inflation as intoxicant}

4.2 With regard to victimization, specific agents are blamed for the dilution of individual wealth through measures that increase the money supply. Such agents supposedly wield tremendous power, controlling stock indexes, commodities markets, and asset prices. Moreover, these agents are portrayed as deceptive, paying lip service to one type of economic situation (for example, a strong US dollar), yet implementing policies that gold bugs believe only serve the interests of the banking industry. As gold bugs repeatedly argue, the public good of monetary policy has been hijacked by private interests that seek the continual devaluation of the dollar and the concentration of wealth into fewer hands.

4.3 As banking industry interests have colonized monetary policy, inflation has become the primary intoxicant for the global economy. As inflation increases asset prices and pushes up wages gold bugs argue that this provides an illusion of increasing wealth. Hence, gold bugs discuss how the value of stock portfolios and homes are given preference above any 'real' measure of prosperity. The global economy becomes 'addicted' to the asset bubbles inflation creates, and policy makers keep going back to inflation as the solution to the problem inflation created in the first instance. This can only be done through the printing of more money - a process one gold bug calls 'barbaric,' and another, the major reason why the US is now the world's largest debtor nation in the world. The technological means to inflation, the printing press, symbolizes a systemic change in which the direct ownership of gold was abandoned for the convenience of owning 'gold backed paper.' For gold bugs this illustrates an institutional separation between the general population and those who control the supply of money. As Ruff (2007) mentions, political interests have made policy makers yield 'to the temptation to simply print more...'

4.4 Analogous to an alcoholic who controls his drinking, gold bugs argue that inflation itself may be controlled by the world's economic authorities in order to keep the post-Bretton-Woods economy intact. The role of the Fed is reduced to a special interest that continuously and unreservedly favors the elite. Under the auspices of promoting economic growth, Fed policy enslaves individuals into greater amount of debt, according to gold bugs. As a conspiracy narrative, gold bug discourse argues that those in positions 
of authority must obfuscate the truth about the addiction to inflation-that debt is part of a vicious cycle in which any drop off in economic activity necessitates interest rate cuts, which produces inflation, reduces real wealth, and slows down the economy further.

\section{Vindication: Inflation as engine of fate}

4.5 With regard to vindication, gold bugs paradoxically portray the same agents who create and control inflation as incompetents doomed to failure. Fed Chair Ben Bernanke is framed as a die-hard inflationist whose policies will destroy the value of fiat currencies and push the price of gold to unprecedented levels. The portrayal of Bernanke begs the question about his true identity: is Bernanke simply blind to the harm he is causing to the global economy and, hence, an example of the incompetence of those in public service? Or, is Bernanke a wolf in sheep's clothing, a friend to the financial industry? Both of these possibilities support a conspiratorial notion about the Fed. On one hand, Bernanke is a bumbling pawn of the faceless agents of Wall Street. On the other, Bernanke is an active agent himself.

4.6 Though Bernanke may be portrayed as cruel and/or naïve, inflation is depicted as an engine of fate that will cause the inevitable collapse of the world financial system. Inflation is a 'non-human agent' (Weinberg 1997) that serves no master, according to gold bugs. By examining how the printing of money leads to less purchasing power, gold bugs' demonstrate a staunch fatalism: barring a return to the gold standard, value cannot be reestablished in a sustainable way. Hence, central banks' successful manipulation of the marketplace in favor of the banking industry is only temporary; the 'true' value of gold protects those who have wisely invested in the precious metal. Based upon the ontological assumption that gold is a 'true' store of value, gold bugs will ultimately be proven right. In this sense, the conspiracy among financial authorities will be short-lived. Vindication does not come from taking up arms, or marching in the streets, but simply by purchasing gold and waiting for the inevitable.

4.7 The assertion that gold bugs will be vindicated and financially rewarded fits in strongly with justice/injustice themes that are crucial to conspiracy narratives. Perceptions of injustice within these narratives almost invariably lead to the demonization of social agents, which adopt myriad forms. To name just a few examples: radicals on the American Far-Right are sworn enemies of government agents that support the 'New World Order' through anti-gun and hence, anti-constitutional legislation reforms (Vertigans 2007), UFOologists claim that scientific evidence of UFOs is quashed by the scientific establishment (Cross 2004), fringe elements within American ethnic groups purport theories that the AIDS virus is part of a concerted genocidal effort (Ross et al. 2006), and the tragic death of Lady Diana in 1997 has been linked to a plot by the UK secret service (the MI6) to assassinate her (Douglas and Sutton 2008).

4.8 With varying degrees of outlandishness, the above and countless other examples of conspiracy narratives are constructed in such a way as to anticipate and subvert those who may be skeptical of a theory's plausibility (Husting and Orr 2007). Conspiracy narratives often overdetermine political, social, and/or economic conditions by invoking hidden social forces that cannot be readily substantiated (Locke 2009). As Kihn (2010) points out, conspiracy is founded upon a degree of speculation that moves beyond conventional standards of empirical evidence testing. Framing contradictory economic indicators within the context of collusive forces, gold bug rhetoric always shifts the discussion back to their inflation-centered ontology. For example, if stock prices are increasing, gold bugs argue that this illustrates an inflationary 'stock market bubble.' If the market crashes, this is an inevitable result of the inflated fiat currency system. Similarly, if the gold price moves lower, it is a result of a concerted effort to manipulate the gold price. If the gold price moves higher, this is a result of the failure of these manipulations. As gold bugs can simultaneously be victimized and vindicated, they are always on the 'right side' of an argument.

\section{Conclusion}

5.1 By repeatedly calling out those who control the world monetary system, labeling such agents as incompetent, self-interested, or both, gold bug discourse strongly appeals to a sense of populism. And given the perceived disjuncture between 'Wall Street' and 'Main Street' in modern society, we can anticipate an increasing audience for gold bug rhetoric. Strongly mirroring a gold bug viewpoint, a 2009 Rolling Stone article, for example, blames the investment bank Goldman Sachs for a host of economic calamities, including the dot-com bubble, the housing bubble and the Great Depression (Taibbi 2009). Such accounts not only provide a theory by which to understand economic problems, they also imply that such understandings can enable self protection. They clarify the conditions under which economic turmoil takes place and they elucidate the specific cause of such conditions.

5.2 Although economic data compiled by government sources often tell a contradictory tale about the health of the economy, stubborn unemployment and stagnating wages provide fertile soil to cultivate enthusiasm for the protection of wealth. Gold bug discourse specifically appeals to this concern as it offers a theory about the origins of monetary wealth, details the forces who manipulate such wealth, and finally, explains how such forces can be defeated. Though the Goliath of Wall Street and the central bankers are formidable foes, they can be defeated if the masses simply have faith in the value of gold, gold bugs argue. The discussion of the value of gold so replete within gold bug discourse begs important questions about perceived uncertainty in contemporary life. A subscription to the belief in the time-tested value of gold serves as a beacon of the desire for intrinsic value within an environment of uncertainty.

\section{References}

ALTHEIDE, David L. (1987) 'Ethnographic Content Analysis.' Qualitative Sociology 10: 65-78.

ASH, Adrian. 23 February (2008) 'Six Months Of Fun, Fun, Fun From The Fed.' Retrieved from: $<$ http://www.gold-eagle.com/editorials_08/ash022308.html> 
AUBIE, Baltan (2008) "Don't Shoot The Messenger." Retrieved from: <http://www.goldeagle.com/editorials_08/baltin032408.html>. 15 March 2010.

BABB, Sarah. (2007) 'Embeddedness, Inflation, and International Regimes: The IMF in the Early Postwar Period.' American Journal of Sociology 113: 128-64.

BALL, R.J. (2007) Inflation and the Theory of Money. Chicago: Aldine Publishing Co. (originally published 1964).

BENTLEY, Darron T. and Earl P. Nelson (eds) (2008) Inflation : Roles, Targeting, and Dynamics. Hauppauge, NY: Nova Science Pub Inc.

BERNANKE, Ben S. (2002) "Deflation: Making Sure "It" Doesn't Happen Here." Speech delivered before the the National Economists Club, Washington, D.C. Retrieved from:

<http://www.federalreserve.gov/boarddocs/speeches/2002/20021121/default.htm>. 11 November 2010.

BRUNO, Michael and Jeffrey D. Sachs. (1985) Economics of Worldwide Stagflation. Cambridge, MA: Harvard University Press.

BRYANT, John. (1997) 'Coordination, Credit, and an Elastic Currency.' Macroeconomic Dynamics 1:77079.

CHAMBLISS, Daniel F. and Russell K. Schutt (2006) Making Sense of the Social World: Methods of Investigation. Thousand Oaks, CA: Pine Forge.

CONSTANTINO Bresciani-Turroni and Lionel Robbins (2007) The Economics of Inflation : A Study of Currency Depreciation in Post-War Germany. New York: Routledge.

COVERT, Juanita. (2003) 'Working Women in Mainstream Women's Magazines: A Content Analysis.' Media Report to Women. 31: 5-14.

CROSS, Anne. (2004) Spring2004, Vol. 27 Issue 1, p3-34, 32p, 1 Black and White Photograph, 1 Illustration, 1 Graph Qualitative Sociology

DENZIN, Norman K. 1989. Interpretive Interactionism. Thousand Oaks, CA CA: Sage.

DIENHART, Ewald; (2007) 'Gold: A 'Bridge over Troubled Water.' Retrieved from:

<http://www.kitco.com/ind/Dienhart/nov14(2007)html>. 14 November 2010

DORSCH, Gary (2007) "Explosive Money Supply Fuels Global Inflation" Retrived from:

$<$ http://www.safehaven.com/article/9069/explosive-money-supply-fuels-global-inflation>. 20 December 2010.

DOUGLAS, Karen. M. and Robbie M. Sutton. (2008) 'The hidden impact of conspiracy theories: perceived and actual influence of theories surrounding the death of princess Diana. The Journal of Social Psychology 148: 210-221.

FEKETE, Antal. (2008) 'Forgotten Anniversary Haunts the Nation.' Retrieved from: <http://www.321gold.com/editorials/fekete/fekete032808.html>. 28 March 2010

FIELD, Alf. (2008) 'Into the Abyss.' Retrieved from:

<http://www.321 gold.com/editorials/field/field010808.html>. 5 January 2010

FIELDS, Echo. (1988) 'Qualitative Content Analysis Of Television News: Systematic Techniques.' Qualitative Sociology 11: 183-193.

FOX, Nick, and Chris Roberts (1999) 'GPs in Cyberspace: The Sociology of a "Virtual Community" The Sociological Review 47: 643-669.

GLASER, Barney. (1978) Theoretical Sensitivity, Mill Valley, CA: Sociology Press.

GLASER, B Barney and Strauss, Anselm. (1967) The discovery of grounded theory. Chicago: Aldine.

GREENBERG, Bradley S. (1980) Life on Television: Content Analyses of U.S. TV Drama . Ablex Publishing Corporation. NY, NY.

GOLDTHORPE, John H. (1983) 'Sociology of Inflation: A Comment.' British Journal of Sociology 34: 498.

HIRSCH, Fred and John H. Goldthorpe eds. 1978. The Political Economy of Inflation. London: Martin Robertson.

HO, K.C., Baber, Zaheer, and Habibul Khondker. (2002) 'Sites' of resistance: Alternative websites and state-society relations. British Journal of Sociology 53: 127-148.

HUSTING, Ginna and Martin Orr. (2007) Dangerous Machinery: 'Conspiracy theorist as a transpersonal strategy of exclusion.' Symbolic Interaction 30: 127-150. 
ING, John. (2008) 'Gold: Lies, Lies And More Lies.' Retrieved from: <http://www.goldeagle.com/editorials_08/ing082908.html>. 4 February 2010

JANKOWSKI, Martin Sanchez. 1991 Islands in the Street: Gangs and American Urban Society. Berkley, CA: UC Press.

KATZ, Howard. (2008) 'Gold - What Happened?' Retrieved from:

<http://www.kitco.com/ind/katz/mar242008a.html>. 24 March 2010

KIHN, Oliver. (2010) Speculative Communication and Its Stigmatization. The Case of Conspiracy Theories. A Contribution to the Sociology of Ignorance. Zeitschrift fur Soziologie 39: 106-123.

KING, G., Keohane, R.O., and Verba, S. (1994). Designing Social Inquiry: Scientific Inference in Qualitative Research. NJ: Princeton University Press.

KLEIN, Hans K. (1999) 'Tocqueville in Cyberspace: Using the Internet for Citizen Associations.' Information Society 15: 213-220.

KRIPPENDORFF, Klaus. (1980) Content Analysis: An Introduction to its Methodology. Beverly Hills, CA: Sage.

LINCOLN, Yvonne S. and Guba, Egon G. Guba (1985). Naturalistic Inquiry. Thousand Oaks, CA: Sage.

LOCKE, Simon. (2009) 'Conspiracy culture, blame culture, and rationalisation.' The Sociological Review 57: 567-585.

OUSHAKIN, Alex Sergei. (2009) 'Stop the invasion!': Money, patriotism, and conspiracy in Russia.' Social Research 76: 71-116.

PETCH, David (2008) A MishMash of Thoughts on Inflation, Gold and the Government. Retrieved from: <http://www.kitco.com/ind/petch/apr012008.html>. 2 April 2010.

PETERS, Alice. (1997) 'A Measure of Inflation.' Canadian Social Trends 45: 13-17.

POMERANZ, Kenneth and Steven Topik (2006) The World That Trade Created: Society, Culture, And The World Economy, 1400 To The Present. Armonk, N.Y. : M.E. Sharpe Publishers.

POTTER, Christopher K. (2007) "Gold Money - Determining an Appropriate US Dollar Exchange Rate. Retrieved from: <http://www.kitco.com/ind/Potter/nov062007A.html>. 6 November 2010.

RAGIN, Charles C. (1994) Constructing Social Research. Thousand Oaks, CA: Pine Forge.

REASON, Matthew and Beatriz Garcia. (2007) 'Approaches to the Newspaper Archive: Content Analysis and Press Coverage of Glasgow's Year of Culture." Media, Culture \& Society 29: 304-331.

ROSS, Michael W, E. James Essien, and Isabel Torres (2006) 'Conspiracy Beliefs about the Origin of HIVIAIDS in Four Racial/Ethnic Groups.' Journal of Acquired Immune Deficiency Syndrome 41: 342-344.

RUFF, Howard. (2007) 'The Watershed Years,' Excerpted and condensed from Chapter 1 of Howard New 2008 Edition of How to Prosper During the Coming Bad Years. Retrieved from:

<http://www.kitco.com/ind/Ruff/nov16(2007)html>. 16 November 2010

SAXENA, Puru. (2007) 'A Tidal Wave!' Retrieved from:

<http://www.kitco.com/ind/Saxena/dec03(2007)html>. December 2010.

SCHIFF, Peter. (2007) 'Not Your Father's Deflation.' Retrieved from: <http://www.goldeagle.com/editorials_05/schiff122107.html>. 21 December 2010.

SCHOON, Darryl Robert. (2008) 'Who's Been Goosing Goldilocks? America \& The Myth Of Free Markets.' Retrieved from: <http://www.321gold.com/editorials/schoon/schoon020508.html>. 5 February 2010.

SOBOLEV, Boris. (2007) 'Is There Danger in this Gold Run?' Retrieved from:

<http://www.321gold.com/editorials/sobolev/sobolev110507.html>. 5 November 2010

SMITH, Michael R. (1982) 'Accounting for Inflation.' British Journal of Sociology. 33: 301-329.

SMITH, Michael R.(1985) 'Accounting for Inflation (again).' British Journal of Sociology. 36: 77-81.

SMITH, Michael R (1992). Power, Norms and Inflation: A Skeptical Treatment. New York: Aldine de Gruyter.

STEWART, Kathleen. (1999) 'Conspiracy Theory's World,' in Paranoia within Reason: A Casebook on Conspiracy as Explanation. Ed. George E. Marcus. Chicago: University of Chicago Press.

STRAUSS, Anselm and Juliet Corbin. (1990) Basics of Qualitative Research: Grounded Theory Procedures and Techniques. Thousand Oaks, CA: Sage Publications.

TAIBBI, Matt. (2009) 'The Great American Bubble Machine: From tech stocks to high gas prices, Goldman Sachs has engineered every major market manipulation since the Great Depression - and they're about to 
do it again.' Rolling Stone Retrieved from: <http://www.rollingstone.com/politics/news/12697/64796>.

TAMBINI , Damian. (1999) 'New Media and Democracy : The Civic Networking Movement.' New Media Society 1: 305-330.

TRIGILIA, Carlo and Nicola Owtram (2002)Economic Sociology: State, Market, and Society in Modern Capitalism. New York: Blackwell Publishing.

VAUGHN, David. 8 November (2007) 'Where is the Excitement?' Retrieved from: <http://www.kitco.com/ind/vaughn/nov08(2007)html>

VERTIGANS, Stephen (2007) 'Beyond the Fringe? Radicalisation within the American Far-Right.' Totalitarian Movements and Political Religions 8: 641-659.

WALLENWEIN, Alex. (2008) 'Gold and the Biflationary Depression.' Retrieved from: <http://www.goldeagle.com/editorials_08/wallenwein011308.html>. 13 January 2010.

WEBB, Eugene J, Donald T Campbell, Richard D Schwartz and Lee Sechrest. (2000) Unobtrusive Measures (Revised Edition). Thousand Oaks, CA: Sage Publications.

WEBER, Robert Phillip. (1985) Basic Content Analysis. Thousand Oaks, Sage.

WEINBERG, Darin. (1997) 'The Social Construction of Non-Human Agency: The Case of Mental Disorder.' Social Problems 44:217-34

WIEGAND, Roger (2007) "FOMC Fomenters of Outrageous Money Collapse." Retrieved from: <http://www.kitco.com/ind/Wiegand/dec112007.html>. 11 December 2010.

WILLIE, Jim. (2007) 'Gold \& Mortgage Failure Avalanche.' Retrieved from: <http://www.321gold.com/editorials/willie/willie121307.html>. 12 December.

WILLIE, Jim (2008) 'Enter 2008: The System Breaks.' Retrieved from:

<http://news.goldseek.com/GoldenJackass/1199461473.php>. 3 January 2010. 